\title{
Phenology of non-biting midges (Diptera: Chironomidae) in peatland ponds, Central Poland
}

\author{
Mateusz Płóciennik, Martyna Skonieczka, Olga Antczak \& Jacek Siciński
}

\author{
Płóciennik, M., Skonieczka, M., Antczak, O. \& Siciński, J. 2018: Phenology of \\ non-biting midges (Diptera: Chironomidae) in peatland ponds, Central Poland. \\ — Entomol. Fennica 29: 61-74.
}

Non-biting midges are one of the most diverse and abundant aquatic insects in peatlands. The Rąbień mire is a raised bog located on the edge of the Lodz Agglomeration in Central Poland. After peat extraction, many ponds remained in the Rąbień area. During the growing season in 2012, adult chironomids were collected by a light trap and a hand net near one of the excavation ponds. The phenology of adult flight period was documented from April to November. Thirty-one species were recorded and assigned to one of five phenology groups. Three parameters reflecting duration of daytime and weather conditions, i.e. air temperature, air humidity, were found to covary significantly with the observed flight periods. Taxa emerging in the spring may be classified as cold-adapted and those collected in the summer only as preferring higher air temperature. Emergence in late summer was related to a shorter duration of daytime.

M. Płóciennik, O. Antczak \& J. Siciński, Department of Invertebrate Zoology and Hydrobiology, University of Lodz, 12/16 Banacha St., Lodz 90-237, Poland; Emails:mplociennik10@outlook.com,ola.antczak10@gmail.com,sicinski@biol.uni.lodz.pl

M. Skonieczka, 22/61 Pitsudskiego St., Aleksandrów Łódzki, 95-070, Poland; email:mynia_89@o2.pl

Received 21 December 2016, accepted 27 September 2017

\section{Introduction}

Besides typically aquatic ecosystems, Chironomidae occur in various semiterrestrial and terrestrial habitats, and are present in natural and human-transformed peatlands. Wrubleski (1987), Walker et al. (1985) and Suren et al. (2008) have shown that Chironomidae are among the dominant groups of aquatic insects in diverse types of bogs and fens, including water bodies. The domination of Chironomidae increases considerably in degraded wetlands (Brady et al. 2002, Ramchunder et al. 2012).
In the last decades in Europe, there have been few comprehensive studies on Chironomidae phenology including springs, streams, ponds and dystrophic lakes (e.g. Cayrou \& Céréghino 2005, Krasheninnikov 2012, Przhiboro \& Paasivirta 2012, Ivković et al. 2015). Whereas Cayrou and Céréghino (2005) and Ivković et al. (2015) present records of the whole life cycles and emergence phenologies of various insects, including Chironomidae, from karst water bodies in the Mediterranean Region, Krasheninnikov (2012) and Przhiboro and Paasivirta (2012) investigated adult and immature stages of Chironomidae in 

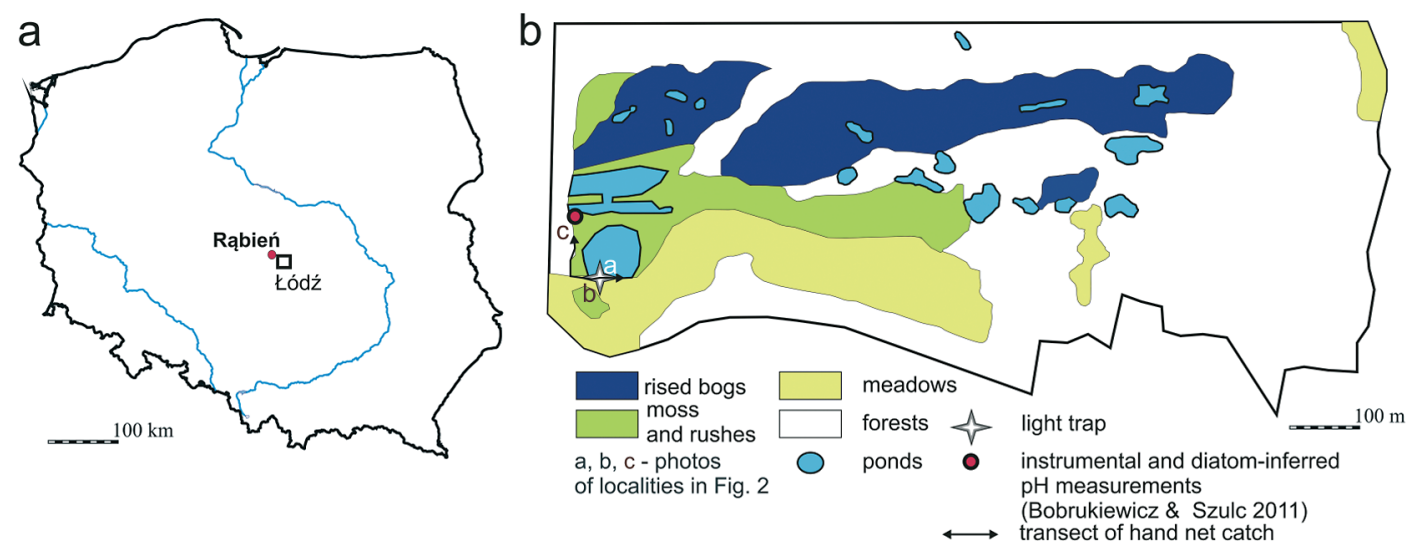

Fig. 1. The Rąbień Bog reserve in Central Poland. - a. Geographic location. - b. Habitat distribution map based on Kucharski et al. (2004).

North-Eastern European streams and lakes. Such a study, conducted on a broad scale, was provided earlier on wetlands and ponds in North America, for example, by Rosenberg et al. (1988) and Dendy (1971). Rosenberg et al. (1988) investigated the life cycle of semiterrestrial taxa (mostly Orthocladiinae) in truly peatland habitats. Dendy (1971) investigated emergence of adults from experimental ponds during studies of three years.

The most recent study of macrobenthos in peatland lakes is by Baars et al. (2014). As they collected pupal exuviae, their information strictly concerns species emergence, but samples were gathered only twice a year, in April and August.

A detailed review of the phenology of Europaen Tanypodinae, Chironomini and Orthocladiinae was made by Vallenduuk and Moller Pillot (2007) and Moller Pillot (2009, 2013). They gathered diverse data from intensive studies to more random observations from all types of habitats across Europe.

In Poland, wetlands cover only $1.9 \%$ of the Lodz region territory. They are mostly fens in river valleys and only few may be classified as raised bogs covering no more than $1 \%$ of the peatland area (Forysiak 2012, Żurek \& Okupny 2015). Although these habitats are so rare, studies on bogs on watersheds constitute an important part of paleolimnological and ecological studies. One of the mires on watersheds is the Rąbien Bog, located at the edge of the Lodz Agglomeration. Some entomological studies at this site concerned Carabidae (Jaskuła 2003, Jaskuła \& Stępień 2012) and moths (Zima 2014). The commu- nities of higher plants and algae were investigated by Mamiński (1987), Kucharski et al. (2004) and Bobrukiewicz and Szulc (2011). More intensive studies have concerned past Chironomidae assemblages from the Late Weichselian $(14,800$ calibrated years before present (cal. BP)) to the beginning of the Subatlantic Period (2,100 cal. BP) (Płóciennik et al. 2015, Słowiński et al. 2016).

To complement subfossil data, research of the current Rąbień's midge fauna was conducted. Ponds left after former peat extraction are an important habitat for chironomids in the reserve. That is why studies were focused on midge appearance close to one of them. The main aim of this research was to recognise the flight periods of the chironomid taxa living at the pond area and their relation to local weather conditions.

\section{Materials and methods}

\subsection{Study area}

The Rąbien Bog (Fig. 1) is located in the Łask Upland, $11 \mathrm{~km}$ northwest of the Łódź city centre, in the village of Rabien AB. The bog covers an area of about 42.5 ha and is located $189 \mathrm{~m}$ above the sea level. The south part of the peatbog is almost totally degraded to meadow-like open habitats and rushes. Peat excavations have been backfilled by construction debris. On the border of the peatbog, there is a first order watershed between the rivers of Bzura and Ner (Forysiak 2012). Cur- 
rently, the Rąbien Bog is protected by law as a nature reserve. The main purpose of the reserve is to preserve a raised bog with Shagnum-Eriophorum peatland, unique in this region. A great part of the reserve is covered with peat pools, which are in various stages of secondary succession, with a total area of 0.4 ha. The youngest peat pools are in the form of small ponds or are filled with brown water and covered with swamp communities. In the oldest ones, there are floating Sphagnum mosses and rhizomes of semiaquatic plants, such as Calla palustris.

\subsection{Sampling and taxonomic identifications}

The site where the light trap was situated is in the west part of the Rąbień Bog (Fig. 1), directly at the largest pond of the reserve (Fig. 2a), with a large surface of exposed water table and a wide reed belt. The older peat pool, fully covered by cattail and reed on the Sphagnum carpet, was also near the light trap (Fig. 2b). The light trap was equipped variably with a 250 or a $500 \mathrm{~W}$ mercury vapour lamp and it was generally operated between 9 and 11 p.m. for at least $1.5 \mathrm{~h}$ after dusk (Table 1). Net catches were taken along the above-described shorelines of the pond (Fig. 1), as well as on the margins of the bog, approx. 100$200 \mathrm{~m}$ away from the light trap (Fig. 2c). Catches were made on the east side of the Rąbien Bog reserve, in Torfowa Street, near the large pond (Fig. 2). Net samples were taken between 6.30 and 8.00 p.m. during sunlight. From April to November 2012, catches of Chironomidae imagines were made during 20 days. Non-biting midges occurred in the period from 18 April to 15 September.

Taxonomic identifications are based on male hypopygia following Langton and Pinder (2007), Giłka (2011) and Makarchenko (2006). Out of 240 caught specimens, 199 were identified to the species or species group level. Taxon names are reported as given in Sæther and Spies (2013), where applicable. Among male hypopygia in collected species of the genus Chironomus Meigen, 1803, C. cf. pilicornis (Fabricius, 1787), C. longistylus Goetghebuer, 1921, C. anthracinus Zetterstedt, 1860 and C. "pallidivittatus" sensu Edwards, 1929, as well as C. cf. plumosus (Linnaeus, 1758) are easier to distinguish. Besides
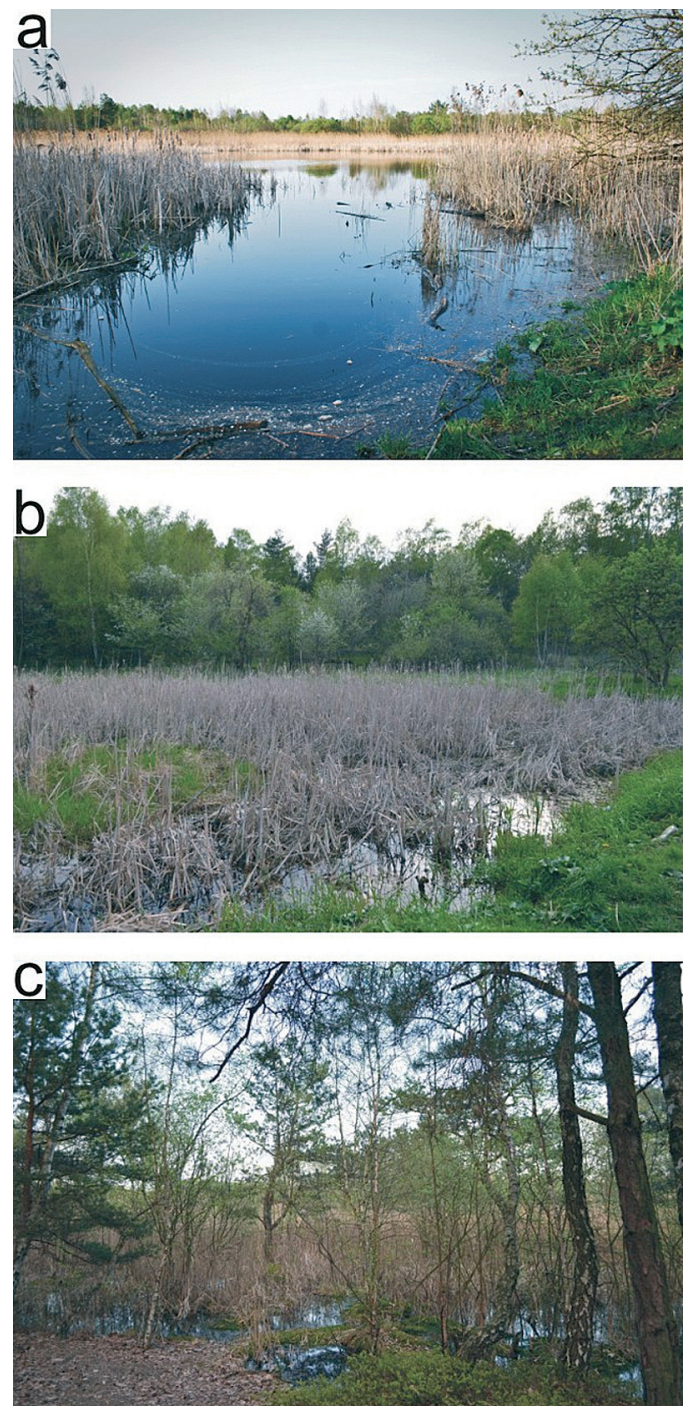

Fig. 2. Photographs of sampling sites. $-a$. Pond. $-b$. Swamp developed after peat extraction, overgrown by reed rushes. - c. Edge of peat bog.

these taxa, two morphotype groups were distinguished: Chironomus piger Strenzke, 1956 group, and Chironomus annularius Meigen, 1818 group. Chironomus gr. piger includes the morphologically similar species C. piger, C. lugubris Zetterstedt, 1850 and C. riparius Meigen, 1804. Chironomus gr. annularius includes $C$. annularius Meigen and C. prasinus Pinder, 1978.

The reference collection of permanent slides of hypopygia mounted in Euparal ${ }^{\circledR}$ is deposited and available at the Department of Invertebrate Zoology and Hydrobiology, University of Lodz. 
Table 1. Meteorological data of the Łódź Lublinek station and times of days recorded on the dates of sample collection in 2012. - A. April-June. B. July-September.

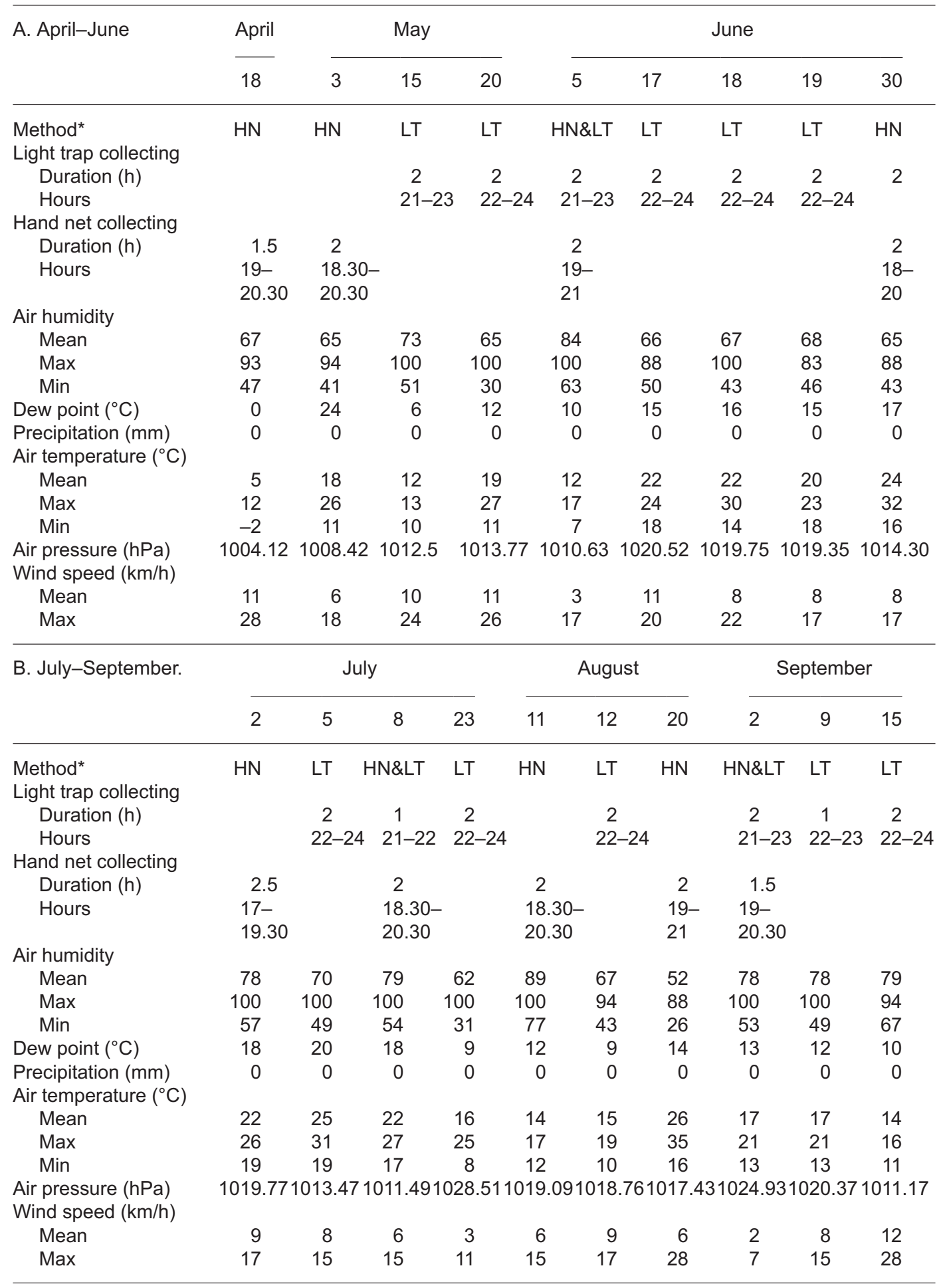

${ }^{*} \mathrm{HN}$ : Hand net, LT: Light trap. 


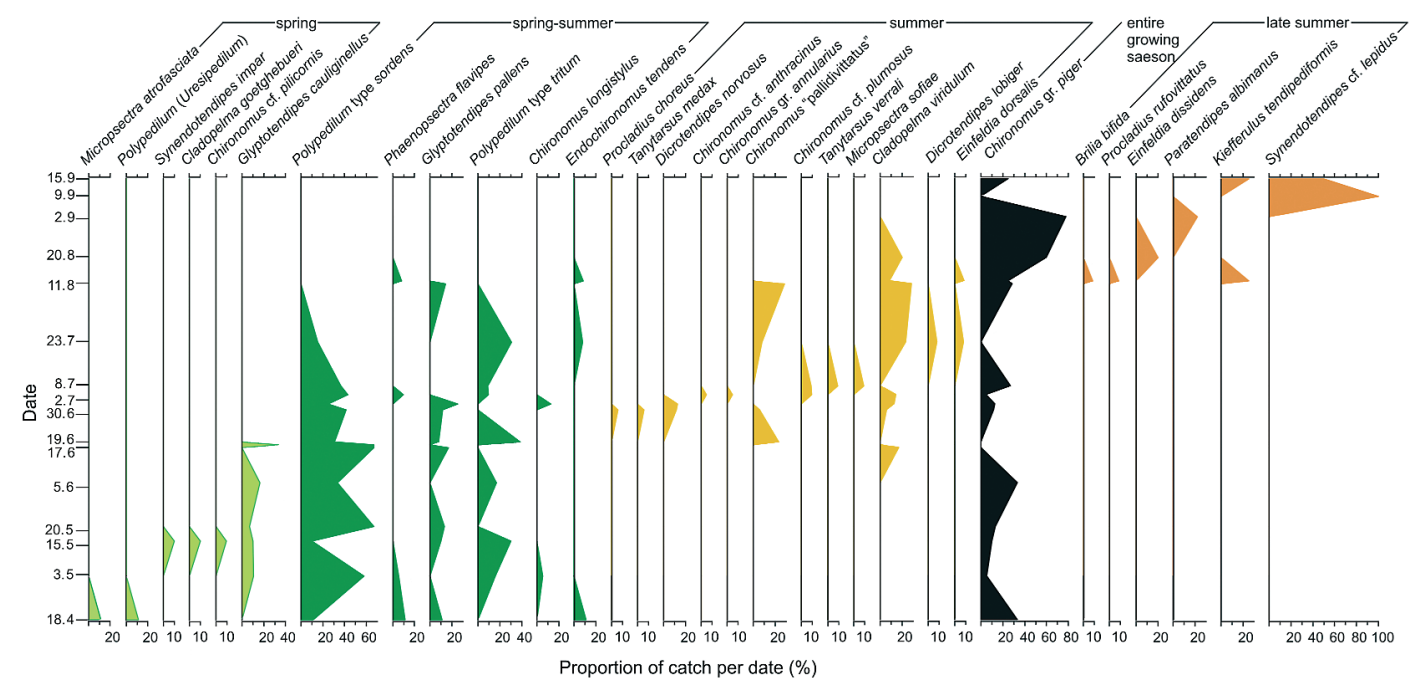

Fig. 3. Species-specific adult male phenologies of recorded chironomid taxa at the Rabień Bog.

\subsection{Meteorological data}

Meteorological data of the Łódź Lublinek station (approx. $12 \mathrm{~km}$ southeast of the study area) were obtained from the www.wunderground.com website. Data on duration of daytime and weather variables (mean day temperature, min. day temperature, max. day temperature, mean day humidity, min. day humidity, max. day humidity, presence of rain, presence of storm, presence of fog) were gathered for all 151 days of the investigated growing season in 2012 (summarized Table 1).

\subsection{Analyses}

Based on the taxon records per sampling date, a phenological diagram was created with $\mathrm{C} 2$ software (Juggins 2007). The taxa were divided into five groups according to their flight seasons: collected in spring only, during spring and summer, in summer only, in late summer only, and throughout the season. Each of the seasons was delineated by the first and last appearances of males within the respective species group. The mean, standard deviation, as well as extreme values of air temperature and humidity were calculated for each swarming season for all the days (not only the sampling days). The mean, shortest and longest duration of daytime for each swarm- ing season was also determined. Significance of the difference between mean values of air temperature, humidity and duration of daytime was tested by the Kruskal-Wallis test (Zar 1984) using STATISTICA software (StatSoft Inc. 2015).

To test for possible relations between the phenological groups of the chironomids and the weather conditions, a Canonical Variate Analysis (CVA) was performed with the use of Canoco 4.5 software (Ter Braak \& Smilauer 2002). Due to autocorrelation, min. day temperature and max. day temperature were excluded from the analysis. An unrestricted full model Monte Carlo permutation using automatic selection was computed to test for significance of the relations between the environmental variables and the species occurrences.

\section{Results}

In the material collected, 31 Chironomidae taxa were identified (Table 2a, b, Fig. 3). The species of the tribe Chironomini were the most abundant. The highest species abundances in the samples were recorded for Chironomus gr. piger and Polypedilum cf. sordens (van der Wulp, 1875), with slightly lower values for Cladopelma viridulum (Linnaeus, 1767), Glyptotendipes pallens (Meigen, 1804) and Polypedilum cf. tritum (Walker, 1856). All other species were considerably less frequent in the samples. 
Table 2. Numbers of collected Chironomidae specimens on the Rąbień Bog, Central Poland, in 2012. - A. AprilJune. B. July-September.

\begin{tabular}{|c|c|c|c|c|c|c|c|c|c|}
\hline \multirow[t]{2}{*}{ A. April-June } & April & \multicolumn{3}{|c|}{ May } & \multicolumn{5}{|c|}{ June } \\
\hline & 18 & 3 & 15 & 20 & 5 & 17 & 18 & 19 & 30 \\
\hline
\end{tabular}

Chironomini

Chironomus gr. annularius (annularius + prasinus)

Chironomus cf. anthracinus

Chironomus longistylus

Chironomus "pallidivittatus"

Chironomus gr. piger (piger, lugubris, riparius)

Chironomus cf. pilicornis

Chironomus cf. plumosus

Cladopelma goetghebueri

Cladopelma viridulum

Dicrotendipes logiber

Dicrotendipes nervosus

Einfeldia dissidens

Einfeldia dorsalis

Endochironomus tendens

Glyptotendipes cauliginellus

Glyptotendipes pallens

Kiefferulus tendipediformis

Paratendipes albimanus

Phaenopsectra flavipes

Polypedilum (Uresipedilum)

Polypedilum cf. sordens

Polypedilum cf. tritum

Synendotendipes impar

Synendotendipes cf. lepidus

Tanytarsini

Micropsectra atrofasciata

Micropsectra sofiae

Tanytarsus mendax

1

Tanytarsus verrali

Tanypodinae

Procladius choreus

1

1

Procladius rufovittatus

Orthocladiinae

Brilia bifida

\begin{tabular}{|c|c|c|c|c|c|c|c|c|c|c|}
\hline Number of specimens & 9 & 19 & 10 & 15 & & & 6 & 3 & 3 & 17 \\
\hline \multirow[t]{2}{*}{ B. July-September } & \multicolumn{4}{|c|}{ July } & \multicolumn{3}{|c|}{ August } & \multicolumn{3}{|c|}{ September } \\
\hline & 2 & 5 & 8 & 23 & 11 & 12 & 20 & 2 & 9 & 15 \\
\hline
\end{tabular}

Chironomini

Chironomus gr. annularius (annularius + prasinus)

Chironomus cf. anthracinus

Chironomus longistylus

1

$\begin{array}{llllllll}1 & 1 & 1 & & 1 & & \\ 1 & 2 & & 1 & & 1 & 2\end{array}$

Chironomus "pallidivittatus"

Chironomus gr. piger (piger, lugubris, riparius) 
Table 2, continued

Chironomus cf. pilicornis

Chironomus cf. plumosus

Cladopelma goetghebueri

Cladopelma viridulum

Dicrotendipes logiber

Dicrotendipes nervosus

Einfeldia dissidens

Einfeldia dorsalis

Endochironomus tendens

Glyptotendipes cauliginellus

Glyptotendipes pallens

Kiefferulus tendipediformis

Paratendipes albimanus

Phaenopsectra flavipes

Polypedilum (Uresipedilum)

Polypedilum cf. sordens

Polypedilum cf. tritum

Synendotendipes impar

Synendotendipes cf. lepidus

Tanytarsini

Micropsectra atrofasciata

Micropsectra sofiae

Tanytarsus mendax

Tanytarsus verrali

Tanypodinae

Procladius choreus

Procladius rufovittatus

Orthocladiinae

Brilia bifida

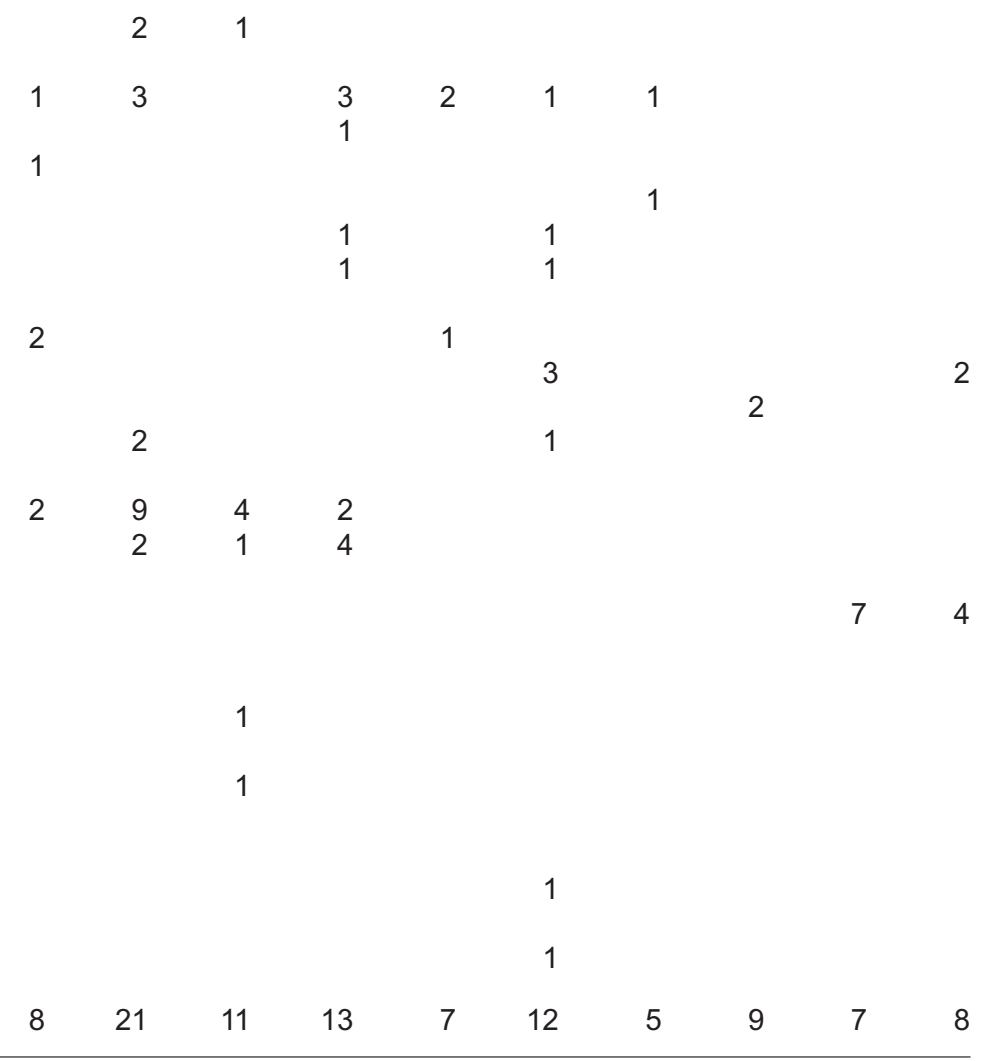

In Fig. 3, each recorded species is assigned to one of the five phenological groups of Chironomidae, ordered according to their subsequent appearance during the growing season. Fig. 4 presents weather specification for the spring, springsummer, summer and late summer seasons, excluding $C$. gr. piger emerging from spring to late summer. The Chironomus gr. piger flight occurs throughout almost the entire growing season.

Three out of the eight investigated variables were significantly associated with flight periods shown by the results of CVA: duration of daytime ( $P=0.002$, explaining $34 \%$ of flight season variability) and the weather variables of mean day air temperature $(P=0.002,9.6 \%)$ and mean day humidity $(P=0.002,7.4 \%)$. Mean day humidity was correlated positively and duration of daytime was correlated negatively with the $1^{\text {st }}$ axis; mean day temperature was negatively correlated with the $2^{\text {nd }}$ axis. The first and second CVA axes explained

$39.4 \%$ and $13 \%$, respectively, of the variance of the species occurrences, as well as $75.2 \%$ and $24.7 \%$ of the variance of the species-environment relations.

\section{Discussion}

The phenology of most of the chironomid species reported from the Rąbień Bog was reviewed for other areas by Vallenduuk and Moller Pillot (2007) and by Moller Pillot (2009, 2013). Our results largely agreed with those reviews, with however some differences. In general, our study indicated that the spring-summer species fly during long daytimes, when air humidity remains relatively low. They are eurythermic. The flight periods of the late summer species are strongly related to a short and decreasing daytime and relatively high air humidity. Whereas the spring- 
summer and the late summer taxa are more closely related to the duration of the daytime and humidity, the species that fly only in spring or only in summer are more related to air temperature. The spring species fly in low air temperature, the longest and the most increasing duration of daytime, as well as low humidity. The taxa, which fly during summer seem to be unrelated to the duration of day-time or humidity but clearly prefer higher mean air temperature for their emergence.

Spring taxa were the earliest flying ones at the study site and were not reported as adults after 15 May, besides G. cauliginellus, whose last males were collected on 19 June. It has usually two generations from June to September (Moller Pillot 2009). It seems that in Rąbien it appears much earlier, being one of the first species that was flying as early as on 3 May. It may be associated with a long and increasing duration of daytime. It is supposed that in Russia $S$. impar has two generations, the first one in April and the second one, possibly incomplete, in autumn (Moller Pillot 2009). In Rąbień, the second generation was not observed. Chironomus pilicornis is a cold stenotherm and has a mostly northern distribution (Moller Pillot 2009). It is considered to have only one generation in Europe and the adults emerge in spring from April to May. The present study confirm the early occurrence and at least cold adaptation of $C$. cf. pilicornis, as far as it can be compared with the true $C$. pilicornis. However, because the collected material is small, it cannot be excluded that some of spring taxa appear also later in summer or even in late summer.

Endochironomus tendens, $P$. tritum, $P$. flavipes, G. pallens and P. sordens are spring-summer species. Nearly all these species have 2-3 generations in Europe (Moller Pillot 2009). In the Rąbień Bog, they also emerge from pupae for a longer part of the growing season. Polypedilum tritum was present during almost the entire growing season. Despite significantly higher temperature in the spring-summer period than in spring, the CVA indicated that these species are rather eurythermic. Together with spring taxa, they are related to lower humidity and longer duration of daytime than the species that emerged as adults only in the late summer.

The group of summer species are $C$. gr. annu- larius, $C$. anthracinus, $C$. "pallidivittatus", $C$. cf. plumosus, $C$. viridulum, $D$. nervosus, $D$. lobiger, E. dorsalis and P. choreus. Moller Pillot (2009) reviews these taxa as having usually two generations and the flight period from about May to about September. Nevertheless, some of them may have only one generation or emerge only once a year, such as $C$. anthracinus, $D$. nervosus and $P$. choreus. Chironomus gr. annularius may have a variable number of generations in Europe, from one to many. Its development is negatively correlated to the duration of daytime but together with $C$. cf. plumosus it is positively correlated to temperature (Moller Pillot 2009). Dicrotendipes nervosus occurs in Central Europe in a variable number of generations - from 2-3 to one generation in England. Another Dicrotendipes species, D. tritomus (Kieffer, 1916) have two generations in south-western France - the first, long, overwintering one, from September to May and the second one - short, lasting from July to August (Cayrou \& Céréghino 2005). Moller Pillot (2009) suggests that if winter is hard with long-lasting ice cover, the first generation may be delayed or very small. Whereas in the present study the winter of 2011/12 was generally within the long-term average temperature, there were periods of quite severe conditions. December was mild $\left(\mathrm{t}_{\text {mean }} 2^{\circ} \mathrm{C}\right.$, $\left.\mathrm{t}_{\text {min }}-9^{\circ} \mathrm{C}, \mathrm{t}_{\text {max }} 10^{\circ} \mathrm{C}\right)$ but January $\left(\mathrm{t}_{\text {mean }}-1^{\circ} \mathrm{C}, \mathrm{t}_{\text {min }}-\right.$ $\left.14^{\circ} \mathrm{C}, \mathrm{t}_{\text {max }} 10^{\circ} \mathrm{C}\right)$ and February $\left(\mathrm{t}_{\text {mean }}-6^{\circ} \mathrm{C}, \mathrm{t}_{\text {min }}-\right.$ $21^{\circ} \mathrm{C}, \mathrm{t}_{\max } 9^{\circ} \mathrm{C}$ ) were quite severe with long periods of temperature below $0^{\circ} \mathrm{C}$. Even in March, temperature decreased to $-9{ }^{\circ} \mathrm{C}$. This might have had an influence on the number of generations and their abundance, and might have delayed flight period of the summer taxa. It is possible that the summer taxa were also present as imagines longer at the investigated site, but their populations were too small to be detected. Apart from that, it is clear from these studies and the data cited by Moller Pillot (2009) that they prefer higher air temperture than the taxa of the other phenological groups.

Kiefferulus tendipediformis, $P$. albimanus, $E$. cf. lepidus, B. carbonaria, $P$. rufovittatus and $B$. bifida can be classified as late summer species in the Rąbien pond. These taxa may be either bivoltine (K. tendipediformis, E. lepidus) or can have one generation (B. carbonaria, $P$. nudisquama, $P$. rufovittatus). Most of them emerge in 

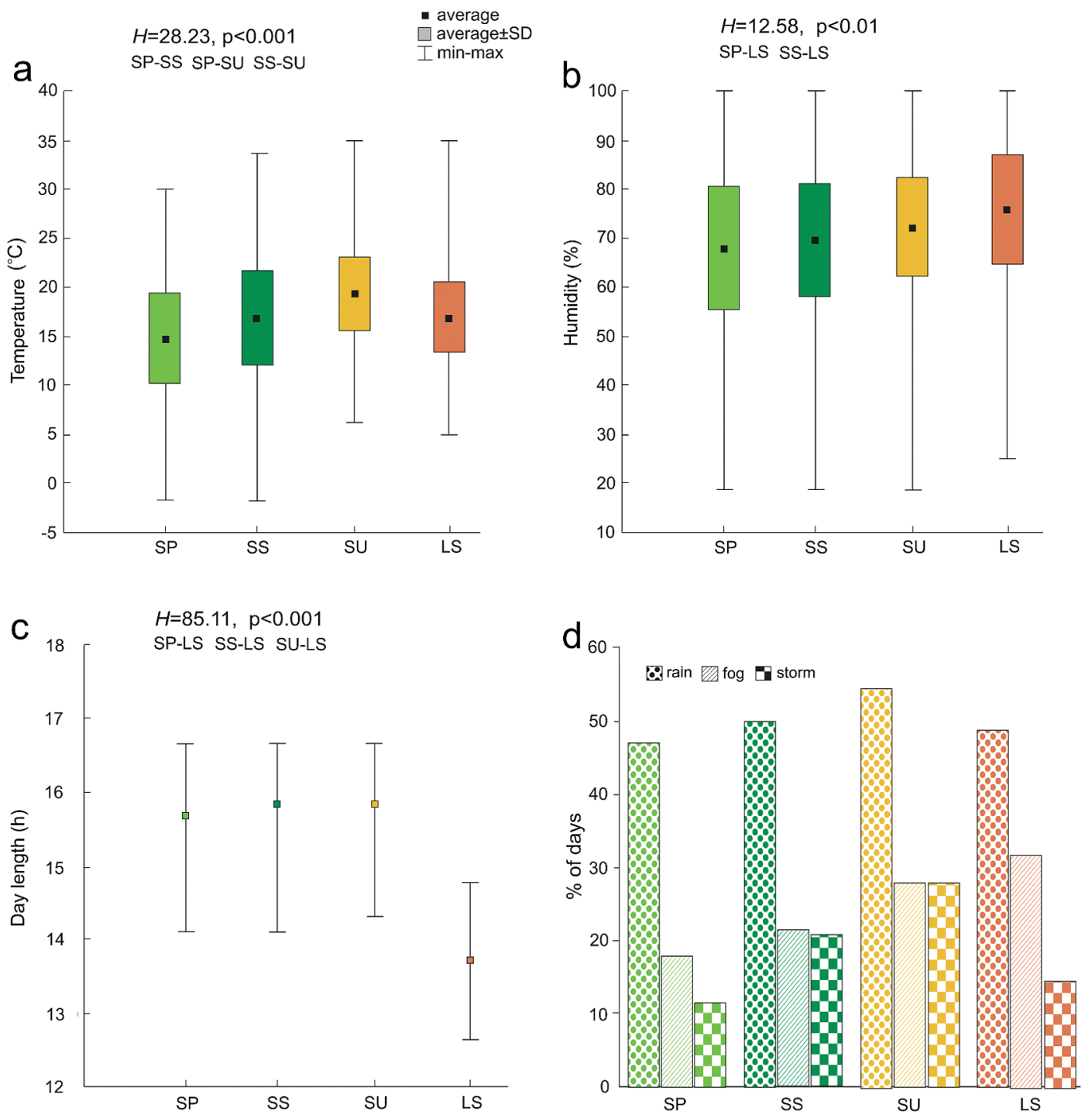

Seasons

Fig. 4. Statistics for selected weather conditions during the phenological seasons. - a. Temperature. $-b$. Humidity. - c. Day length. - d. Percent of days with rain, fog or/and storm; as there were often days with both rain and storm, or both fog and rain, this does not amount to $100 \%$. In connection of Kruskal-Wallice tests, significant differences between the seasons are shown as pairs (e.g. SP-LS). Spring (SP), spring-summer (SS), summer (SU), late summer (LS).

Europe from May to September. Paratendipes albimanus can have two generations in stagnant waters but low temperature and low trophy (i.e. low concentration of biogenic compounds in the water and bottom sediments) may prevent the appearance of the second generation. In South England, it has one generation with $4^{\text {th }}$ larval instar appearing in July-August. Brillia bifida can emerge all the year round in Western Europe (Vallenduuk \& Moller Pillot 2007, Moller Pillot 2009, 2013). Only single specimens of the late summer taxa were collected in the present study. Therefore, it cannot be excluded that some adults emerged earlier but were not collected. Our re- 
sults showed that the late summer species emerged in a period with significantly shorter duration of daytime and relatively higher humidity than the taxa of the other phenological groups.

Chironomus piger often occurs in Europe even in 5-6 generations per year (Moller Pillot 2009), i.e. througout the growing season. Taxa of $C$. gr. piger have similar phenology in the Rąbien Bog. Csabai et al. (2015) recorded C. piger on peaty shores of water reservoirs and small, temporary ponds with a wide belt of rushes.

The present study does not concern winter activity of Chironomidae, but, for example, Baranov and Ferrington (2013) as well as SoszyńskaMaj et al. (2015) document winter activity of adult non-biting midges in Europe, even on the snow.

The species recorded in the Rąbień Bog come mainly from a nearby pond, whereas Rosenberg et al. (1988) studied the phenology of Chironomidae developing on peatlands in Canada. Peatlands surrounding lakes in the Experimental Lake Area are dominated by semiterrestrial Orthocladiinae (Rosenberg et al. 1988). In that study, the majority of the abundant species were univoltine with synchronous emergences. Their emergence started in May and ended in September, but $95 \%$ of the taxa emerged mainly in late spring and early summer. That timing allows larvae to develop to a sufficiently advanced instar to survive summer peat desiccation, and then grow large enough during moist autumn to survive freezing in winter (Rosenberg et al. 1988). Similarly, Krasheninnikov (2012) showed that most of Orthocladiinae taxa in Middle Ural river valleys emerge from May to August.

In Irish dystrophic lakes, most of invertebrate assemblages, mainly insects, did not show any significant differences of species composition in spring (April) and late summer (August). Nevertheless, Chironomidae significantly differed in species composition in the two sampling periods (especially in lakes with low $\mathrm{pH}$ ) (Baars et al. 2014). Chironomini clearly dominated at the margin of the pond at the Rąbien Bog, whereas in Irish lakes within peatlands also many Orthocladiinae, Tanypodinae and Tanytarsini were recorded. In Ireland, imagines of $C$. viridulum and $P$. flavipes occur in late summer, whereas in the Rabień pond $P$. flavipes emerged earlier, since April, which is the case also in Croatia (Ivković et al. 2015). In Ireland, adults of $C$. anthracinus and $P$. choreus occur already in April and August, whereas at the Rąbień pond both species were observed as single individuals from June to early July.

The abundances of the collected chironomids was surprisingly low in the present study. This may be associated with the sampling methods as not all midges are attracted to light, and the net sampling was conducted mostly in the late afternoon and early evening. Taxa active during different times of day might have been omitted. The light trap and the net sampling transect were also located directly at the pond, which might have excluded Orthocladiinae from the catch, typically dominating on peatlands (Rosenberg et al. 1988, Przhiboro \& Paasivirta 2012). On the other hand, the $\mathrm{pH}$ of the nearby pond was also low (Bobrukiewicz \& Szulc 2011), the diatom-inferred $\mathrm{pH}$ ranged between 3.75 and 5.6. The low $\mathrm{pH}$ is unfavourable for most Chironomidae and limits the number of taxa and the midge abundance in the water body (Brooks et al. 2007). The number of larval subfosssils in lakes undergoing paludification is also much lower than in other water bodies with the circumneutral or almost neutral $\mathrm{pH}$, which was recorded at sites in Central Poland including Rąbień palaeolake (Płóciennik et al. 2011, Pawłowski et al. 2015, Płóciennik et al. 2015). At the light trap locality (Fig. 2a) of our present study, presence of pupal exuviae on the water was also surveyed. Their number was very low and often hardly observed. Przhiboro and Paasivirta (2012) used other, more precise methods of estimating abundance and species composition on moss carpets in Karelia. There, the abundances of collected chironomids were much higher at Bol'shoe Rakovoe and Okhotnich'e Lakes than reported here from the investigated light trap at Rąbień reserve.

In the present study, CVA demonstrated that mean day air temperature, mean day air humidity and day length may significantly influence the flight period of investigated Chironomidae species. This is consistent with the general findings that temperature is the most important factor influencing midge physiology, life cycle and community structure (Brooks 2006, Barley et al. 2006, Woodward \& Shulmeister 2006, Brooks et 


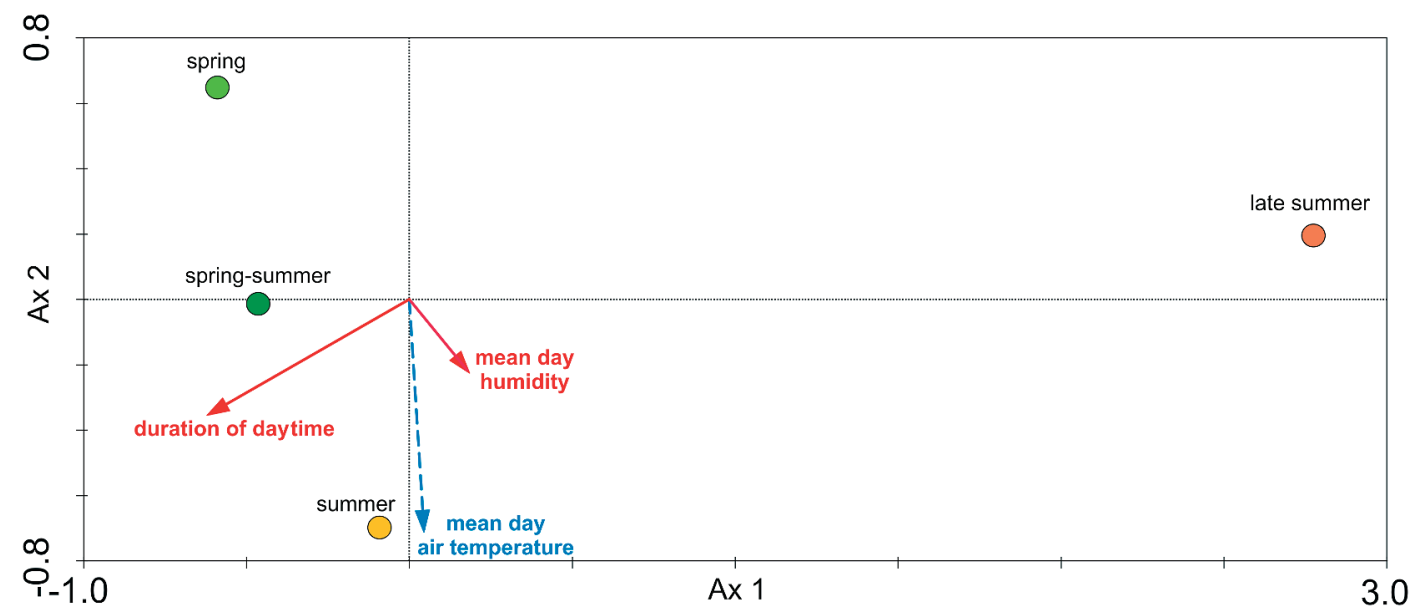

Fig. 5. Results of the Canonical Variate Analysis (CVA) of the flight periods of chironomids of different assemblages of the growing season at the Rąien Bog in 2012. Solid arrows: factors correlated to $1^{\text {st }} \mathrm{CVA}$ axis, dashed arrow: factor correlated to $2^{\text {nd }} \mathrm{CVA}$ axis.

al. 2007, Bouchard 2007, Rees et al. 2008, Luoto et al. 2014, Nazarova et al. 2015). At Rąbień pond, the species emerging only in spring and only in summer seem to be most related to the mean temperature but in the opposite direction for these two groups (Fig. 5). The flight period of taxa emerging through the nearly whole growing season or in late summer is rather linked to other factors, like local habitat or duration of daytime.

Płóciennik et al. (2015) studied the history of Chironomidae assemblages in the Rąbien Bog from the formation of the paleolake in the late Weichselian to its disappearance in the late Holocene. The abundance and species richness of Chironomidae were the highest in the late Weichselian. The concentration of subfossils in the sediments and the number of recorded species sharply declined because of paludification and water level decrease in the Holocene. Since 3600 cal. $\mathrm{BP}$, it has formed communities of semiterrestrial orthoclads typical of Sphagnum bogs (Słowiński et al. 2016). Taxa recorded in these studies inhabit mainly the pond developed after the peat extraction. In the Rąbien sequence, they were mainly observed from the Late Glacial to the Middle Holocene (up to 4,470 cal. BP). Płóciennik et al. (2015) distinguished five stages in Late GlacialHolocene history of the Rąbień palaeolake: $X_{1}$, $\mathrm{X}_{2}, \mathrm{X}_{3}, \mathrm{Y}_{1}, \mathrm{Y}_{2}$. Some of the taxa recorded at the pond in 2012 may be easily assigned to the morphotypes reported from the Rąbień Late Glacial stages $\mathrm{X}_{2}, \mathrm{Y}_{2}$ (Chironomus type anthracinus, Chironomus type plumosus, Tanytarsus type medax), the Late Glacial-Early Holocene stage $\mathrm{Y}_{1}$ (Cladopelma type goetghebueri), and the Middle Holocene stage $\mathrm{X}_{3}$ (Dicrotendipes, Glyptotendipes pallens) (see Płóciennik et al. 2015). At that time, Rąbień was a shallow, mesoand later eutrophic overgrown lake (Płóciennik et al. 2015).

Effects of human activity before the establishment of the reserve, visible in the form of many small reservoirs in various stages of succession, have contributed to the re-appearance of typical limnetic taxa. They are mostly common, eurytopic species, present in many other anthropogenic reservoirs in Central Poland (Płóciennik \& Klukowska 2010). Surprisingly, this research did not record any taxa typical to peatland habitats from the Orthocladiinae subfamily, such as Limnophyes or Pseudorthocladius, which are present in the subfossil material from Rabień (Słowiński et al. 2016) and in the nearby Żabieniec bog (Lamentowicz et al. 2009). Most likely this is due to the location of the light trap close to the local pond, but not directly at the lobe of Shagnum-Eriophorum mire. Relatively high species richness of Chironominae compared to the other subfamilies at the pond habitats was also documented e.g. by Dendy (1971). 


\section{Conclusions}

The present study was aimed to cast light on the flight periods of chironomids in a peatland pond area but not to reflect the entire life cycles of the recorded species. From the results of CVA (Fig. 5) and the analysis of weather conditions of flight seasons (Fig. 4), it is clear that the primary factor that determines, at least indirectly, the emergence of the investigated groups of species is air temperature. Air humidity divides taxa into ones emerging early and later in the growing season. The third factor that was statistically significant was duration of daytime, which was, as expected, shorter for the late emerging species.

The present study is based on a relatively small material, so it cannot be excluded that midges were present at the pond longer as imagines but their abundances were too small to be recorded. Local conditions (e.g. water chemical composition) and specific weather (e.g. in winter) of the 2012 season might have limited the length of the flight period of the multivoltine taxa. Chemical and physical conditions in Rąbień pond, where the light trap was situated, were not measured. It can be supposed that the pool developed after peat extraction and, surrounded by bog lobes, should have low $\mathrm{pH}$. It means that the conditions in the ponds could be unfavourable for chironomids, and species, which elsewhere appear much longer as imagines, might have only low abundances in Rąbień pond.

Whereas it is difficult to assess the flight period of certain species recorded as few specimens, phenological stages of well-defined groups of taxa are clearer. The phenology of the midges of the ponds are different than in the peatlands investigated by Rosenberg et al. (1988). Their research reflects peat bog communities more strictly as they are based on emergence traps located directly on the bog surface. Midge composition even in strongly acidified lakes (Walker et al. 1985) may be much more similar to the investigated one than to peatlands sensu stricto (Rosenberg et al. 1988). Lake paludification and final terrestrialisation cause gradual pauperisation of midge communities (Płóciennik et al. 2015, Słowiński et al. 2016). Peat extraction may considerably contribute to the appearance of small water bodies, and thus the reappearance of lim- netic species, which according to these studies are, nevertheless, mostly common generalists.

Acknowledgements. The research in the Rąbień Bog was co-financed by a grant from the Polish Ministry of Science and Higher Education (N N306 276735). We would like to thank professional translator Marta Koniarek for linguistic corrections.

\section{References}

Baars, J.-R., Murray, D. A., Hannigan, E. \& Kelly-Quinn, M. 2014: Macroinvertebrate assemblages of small upland peatland lakes in Ireland. — Biology and Environment: Proceedings of the Royal Irish Academy 114B: 233-248.

Baranov, V. \& Ferrington, L. C. Jr. 2013: Hibernal Emergence of Chironomidae in Crimea (Ukraine). - Chironomus, Newsletter on Chironomidae Research 26: 33-40.

Barley, E.M., Walker, I.R., Kurek, J., Cwynar, L.C., Mathewes, R.W., Gajewski, K. \& Finney, B.P. 2006. A northwest North American training set: distribution of freshwater midges in relation to air temperature and lake depth. - Journal of Paleolimnology 36: 295-314.

Bobrukiewicz, K. \& Szulc, B. 2011: Wpływ wybranych parametrów fizykochemicznych wody na zbiorowiska okrzemek w rezerwacie "Torfowisko Rąbień" (Polska Środkowa). - In: Gwoździński K. (ed.), Bory Tucholskie i inne obszary leśne. Ochrona, monitoring, edukacja: 85-94. Wydawnictwo Uniwersytetu Łódzkiego, Łódź, 529 pp. [In Polish with English summary.]

Brady, J. V., Cardinale, B. J., Gathman, J. P. \& Burton, T. M. 2002: Does facilitation of faunal recruitment benefit ecosystem restoration? An experimental study of invertebrate assemblages in wetland mesocosms. Aquatic Invertebrate Recruitment in Wetland Restoration 10: 617-626.

Bouchard, R. W. 2007: Phenology and taxonomic composition of lotic Chironomidae (Diptera) communities in contrasting thermal regimes. $\mathrm{PhD}$ thesis, University of Minnesota. $411 \mathrm{pp}$.

Brooks, S. J. 2006: Fossil midges (Diptera: Chironomidae) as palaeoclimatic indicators for the Eurasian region. — Quaternary Science Reviews 25: 1894-1910.

Brooks, S. J., Langdon, P. G. \& Heiri, O. 2007: The Identification and Use of Palaearctic Chironomidae Larvae in Palaeoecology. - Quaternary Research Association, London. 276 pp.

Cayrou, J. \& Céréghino, R. 2005: Life-cycle phenology of some aquatic insects: implicationsfor pond conservation. - Aquatic Conservation: Marine and Freshwater Ecosystems 15: 559-571.

Csabai, Z., Boda, P., Boda, R., Bódis, E., Danyik, T., Deák, Cs., Farkas, A., Kálmán, Z., Lőkkös, A., Málnás, K., Mauchart, P. \& Móra, A. 2015: Aquatic macro- 
invertabrate fauna of the Kis-Sárrét nature protection area with first records of five species from Hungary. - Acta Biologica Debrecina Supplementum Oecologica Hungarica 33: 9-70.

Dendy, J. S. 1971: Phenology of midges in experimental ponds. - The Canadian Entomologist 103: 376-380.

Forysiak, J. 2012: Zapis zmian środowiska przyrodniczego późnego vistulianu i holocenu w osadach torfowisk regionu łódzkiego. - Acta Geographica Lodziensia 99: 7-164. [In Polish with English summary.]

Giłka, W. 2011: Ochotkowate - Chironomidae, plemię: Tanytarsini, postaci dorosłe, samce. (Non-biting midges - Chironomidae, tribe Tanytarsini, adult males). - Klucze do oznaczania owadów Polski. (Keys for the identification of Polish insects). No. 177, b XXVIII, Muchówki - Diptera, zeszyt 14b. Polskie Towarzystwo Entomologiczne, Biologica Silesiae, Wrocław. [In Polish.]

Ivković, M., Miliša, M., Baranov, V. \& Mihaljević, Z. 2015: Environmental drivers of biotic traits and phenology patterns of Diptera assemblages in karst springs: The role of canopy uncovered. — Limnologica 54: 44-57.

Jaskuła, R. 2003: Biegaczowate (Coleoptera: Carabidae) w wybranych rezerwatach okolic Łodzi. - Parki Narodowe i Rezerwaty Przyrody 22(4): 549-560. [In Polish with English summary.]

Jaskuła, R. \& Stępień, A. 2012: Ground beetle fauna (Coleoptera: Carabidae) of protected areas in the Łódź Province. Part I. Nature reserves. — Fragmenta Faunistica 55: 101-121.

Juggins, S. 2007: C2 version 1.5 user guide. Software for Ecological and Palaeoecological Data Analysis and Visualisation. - Newcastle University, Newcastle. $73 \mathrm{pp}$.

Krasheninnikov, A. B. 2012: Phenology of some chironomid species (Diptera, Chironomidae) of the Middle Urals. - Fauna norvegica 31: 55-63.

Kucharski, I., Kurzac, M., Rakowska, B. \& Sitkowska, M. 2004: Changes in the flora and vegetation of the Torfowisko Rąbień reserve near Łódź (Poland), and their proposed conservation methods. - Nature Conservation 60: 49-62.

Lamentowicz, M., Balwierz, Z., Forysiak, J., Płóciennik, M., Kittel, P., Kloss, M., Twardy, J., Żurek, S. \& Pawlyta, J. 2009: Multiproxy study of anthropogenic and climatic changes in the last two millennia from a small mire in central Poland. - Hydrobiologia 631: 213230.

Langton, P. H. \& Pinder, L. C. V. 2007: Keys to the adult male Chironomidae of Britain and Ireland. - Freshwater Biological Association (FBA), Far Sawrey. 240 pp.

Luoto, T. P., Kaukolehto, M., Weckström, J., Korhola, A. \& Väliranta, M. 2014: New evidence of warm earlyHolocene summers in subarctic Finland based on an enhanced regional chironomid-based temperature calibration model. - Quaternary Research 81: 50-62.

Mamiński, M. 1987: Szata roślinna projektowanego rezerwatu "Rąbień" koło Aleksandrowa Łódzkiego. — Ac- ta Universitas Lodziensis, Folia Botanica 5: 3-39. [In Polish.]

Makarchenko, E. A. 2006: Chironomidae-Komary-zvoncy. - In: Lelieja, A. C. (ed.), - Diptera. Tom VI, czast 4: 204-734. RFFI, Vladivostok, 934 pp. [In Russian.]

Moller Pillot, H. K. M. 2009: Chironomidae larvae. Biology and ecology of the Chironomini. - KNNV Publishing, Zeist. 270 pp.

Moller Pillot, H. K. M. 2013: Chironomidae Larvae, Volume 3: Biology and Ecology of the Aquatic Orthocladiinae. - KNNV Publishing, Zeist. 312 pp.

Nazarova, L., Self, A. E., Brooks, S.J., van Hardenbroek, M., Herzschuh, U. \& Diekmann, B. 2015: Northern Russian chironomid-based modern summer temperature dataset and inference models. - Global and Planetary Change 134: 10-25.

Pawłowski, D., Kowalewski, G., Milecka, K., Płóciennik, M., Woszczyk, M., Zieliński, T., Okupny, D., Włodarski, W. \& Forysiak, J. 2015: A reconstruction of the palaeohydrological conditions of a floodplain: a multiproxy study from the Grabia River valley mire, central Poland. - Boreas 44: 543-562.

Płóciennik, M. \& Klukowska, M. 2010: Ochotkowate (Diptera: Chironomidae). — In: Jaskuła, R. \& Tończyk G. (eds), Owady (Insecta) Parku Krajobrazowego Wzniesień Łódzkich: 139-145. Dyrekcja Parku Krajobrazowego Wzniesień Łódzkich, MazowieckoŚwiętokrzyskie Towarzystwo Ornitologiczne, Łódź. 213 pp. [In Polish.]

Płóciennik M., SelfA., Birks, H. J. B. \& Brooks, S. J. 2011: Chironomidae (Insecta: Diptera) succession in Żabieniec bog and its palaeo-lake (central Poland) through the Late Weichselian and Holocene. - Palaeogeography, Palaeoclimatology, Palaeoecology 307: 150 167.

Płóciennik, M., Kruk, A., Michczyńska, D. J. \& Birks, H. J. B. 2015: Kohonen artificial neural networks and the IndVal index as supplementary tools for the quantitative analysis of palaeoecological data. - Geochronometria 42: 189-201.

Przhiboro, A. \& Paasivirta, L. 2012: Chironomidae of semiaquatic lake shore habitats in the Karelian Isthmus (northwestern Russia). - Fauna norvegica 31: 87-94.

Ramchunder, J. S., Brown, L. E. \& Holden, J. 2012: Catchment-scale peatland restoration benefits stream ecosystem biodiversity. - Journal of Applied Ecology 49: 182-191.

Rees, A. B. H., Cwynar, L. C. \& Cranston, P. S. 2008: Midges (Chironomidae, Ceratopogonidae, Chaoboridae) as a temperature proxy: A training set from Tasmania, Australia. - Journal of Paleolimnology 40: 11591178.

Rosenberg, D. M., Wiens, A. P. \& Bilyj, B. 1988: Chironomidae (Diptera) of peatlands in northwestern Ontario, Canada. - Holarctic Ecology 11: 19-31.

Sćther, O. A. \& Spies, M. 2013: Fauna Europaea: Chironomidae. - In: Beuk, P. \& Pape, T. (eds), Fauna Europaea: Diptera Nematocera. Fauna Europaea version 2.6. (http://www.faunaeur.org/?no_redirect=1). (Site visited on 1 September, 2016) 
Słowiński, M., Marcisz, K., Płóciennik, M., Obremska, M., Pawłowski, D., Okupny, D., Słowińska, S., Borówka, R.K., Kittel, P., Forysiak, J., Michczyńska, D. J. \& Lamentowicz M. 2016: Drought as a stress driver of ecological changes in peatland - A palaeoecological study of peatland development between $3500 \mathrm{BCE}$ and 200 BCE in central Poland. - Palaeogeography Palaeoclimatology Palaeoecology 461: 272-291.

Soszyńska-Maj, A., Paasivirta, L. \& Giłka, W. 2015: Why on the snow? Winter emergence strategies of snow-active Chironomidae (Diptera) in Poland. - Insect Science 23: 754-770.

StatSoft Inc. 2015. STATISTICA (data analysis software system), version 12. 2015. Available from www.statsoft.com

Suren, A. M., Lambert, P., Image, K. \& Sorrell, B. K. 2008: Variation in wetland invertebrate communities in lowland acidic fens and swamps. - Freshwater Biology 53: 727-744.

Ter Braak, C. J. F. \& Smilauer, P. 2002: CANOCO, Software for Canonical community Ordination (ver. 4.05). - Centre for Biometry, Wageningen. 500 pp.

Vallenduuk, H. J. \& Moller Pillot, H. K. M. 2007: Chironomidae larvae of the Netherlands and adjacent lowlands. General ecology and Tanypodinae. - KNNV, Zeist. 143 pp.
Walker, I. R., Fernando, C. H. \& Paterson, C. G. 1985: Association of Chironomidae (Diptera) of shallow, acid, humic lakes and bog pools in Atlantic Canada, and a comparison with an earlier paleoecological investigation. - Hydrobiologia 120: 11-22.

Woodward, C. \& Shulmeister, J. 2006: New Zealand chironomids as proxies for human-induced and natural environmental change: Transfer functionsfor temperature and lake production (chlorophyll a). — Journal of Paleolimnology, 36: 407-429.

Wrubleski, D. A. 1987: Chironomidae (Diptera) of peatlands and marshes in Canada. - In: Rosenberg, D. M. \& Danks, H. V. (eds), Aquatic insects of peatlands and marshes in Canada. - The Memoirs of the Entomological Society of Canada 119: $141-161$.

Zar, J. H. 1984: Biostatistical Analysis. — Prentice-Hall Inc., Englewood Cliffs. 960 pp.

Zima, A. 2014: Motyle nocne (Macrolepidoptera: Heterocera) rezerwatu Rąbień. Master thesis. - University of Lodz. 48 pp. [In Polish with an English summary.]

Żurek, S. \& Okupny, D. 2015: Torfowiska regionu łódzkiego. - Studia Limnologica et Telmatologica 9: 5969. [In Polish with an English summary] 